DOI: https://doi.org/10.15407/techned2021.03.003

\title{
REGULATION OF OUTPUT DYNAMIC CHARACTERISTICS OF ELECTRIC DISCHARGE INSTALLATIONS WITH RESERVOIR CAPACITORS
}

\author{
A.A. Shcherba ${ }^{1^{*}}$, N.I. Suprunovska ${ }^{1 * *}$, M.A. Shcherba ${ }^{2 * * *}$, S.S. Roziskulov ${ }^{1 * * * *}$ \\ ${ }^{1}$ Institute of Electrodynamics of National Academy of Sciences of Ukraine, \\ Pr. Peremohy, 56, Kyiv, 03057, Ukraine, \\ ${ }^{2}$ NTUU "Igor Sikorsky Kyiv Polytechnic Institute", \\ Pr. Peremohy, 37, Kyiv, 03056, Ukraine, \\ e-mail: iednat1@gmail.com \\ e-mail: m.shcherba@gmail.com
}

The paper reveals the dependences of the output dynamic characteristics of semiconductor electric discharge installations (EDIs) with reservoir capacitors on the features of the change in the value of their capacitance. In particular, it is substantiated that for any fixed discharge duration less than the duration of reaching the maximum discharge current, an increase in the capacitance of such storage devices causes an increase in the value of the final discharge current both at aperiodic and oscillatory discharges in the linear resistance of the technological load. The change in the value of the discharge current in the load in the case of forced interruption of this current at a certain moment of time is investigated. Based on the obtained regularities, the authors of the work proposed to use the capacitance of the EDI's capacitor, which is larger than capacitance required to implement the maximum value of the discharge current in the load. Using a capacitor with a larger capacity and a fully controlled semiconductor switch in the discharge circuit of the EDI, it is possible to obtain the required maximum current value at a shorter duration of the discharge process. Thus, it is possible to regulate the main dynamic parameters of pulse currents in the load - the rate of their rise and/or their duration by changing the value of the capacitance of the discharge capacitor EDI. This approach is expedient for increasing the productivity of EDIs, focused on the production of dispersed spark powders of metals and alloys. References 15, figures 3 .

Key words: capacitor discharge, rate of current rise, transient process, capacitor capacity, discharge duration.

Introduction. Linear and nonlinear reservoir capacitors are usually used in electric discharge installations (EDIs) in order to implement the high pulse currents and powers in technological load. Such high currents and powers cannot be consumed from a power supply network, but they are necessary for realization of modern discharge-pulse technologies [1-4], in particular for treatment of various materials and obtaining spark eroded powders [5-9]. In this case, the spark load, which is included only in the discharge circuit of capacitors, has parametric, nonlinear and stochastic properties [10-12], so this load affects the final voltages of the capacitors $[3,4]$, as well as the nature of the transients in the discharge circle [10].

One of the main electro-dynamic problems in the improvement of pulse current generators for electric discharge installations is an increase in the rate of rise of currents in a technological load, since this causes an increase in the force effect of these currents on the load. Since the instantaneous active power released in the load is directly proportional to the values of its active resistance and the quadratic value of the discharge (pulse) current, an increase in the force effect on the technological load is actually achieved by the formation of high pulse currents of short durations in the load.

For example, in installations for volumetric electro-spark dispersion (VESD) of metals and alloys in a dielectric liquid, an increase in the rate of rise of discharge currents and a reduction in their duration makes it possible to decrease the size of dispersed particles obtained due to spark erosion $[6,7,9,13]$. Therefore, this approach can be used as the basis for the method of producing spark eroded nanosized powders of metals and alloys, as well as electrochemically and biologically active colloidal systems.

The aim of this work is to determine the features and regularities of transient processes of the discharge of a reservoir capacitor of an electric discharge installation to its technological load in order to identify the possibilities for control of the rate of rise and/or duration of the discharge current in the load when changing the parameters of the discharge circuit and the conditions of the capacitor discharge.

(c) Shcherba A.A., Suprunovska N.I., Shcherba M.A., Roziskulov S.S., 2021

ORCID ID : * http://orcid.org/0000-0002-0200-369X ; ** https://orcid.org/0000-0001-7499-9142 ;

*** https://orcid.org/0000-0001-6616-4567; **** https://orcid.org/0000-0001-9234-7324 
Change in the rate of rise of discharge currents in the electrical circuit of spark-erosive loads. A layer of metal granules between electrodes immersed in a dielectric liquid is a technological load in EDIs for producing spark eroded particles. According to research, the electrical resistance $R_{\text {load }}$ of all types of spark loads is non-linear. Its value depends on many factors: the value of the discharge current and the rate of its change, the duration and frequency of the discharge pulses, the physicochemical properties of the liquid and granules, the size of both the granules themselves and their layer, the design and technological parameters of the electric discharge chamber $[5,6,8]$. The nonlinear dependence of the spark load resistance on many parameters makes it difficult to use accurate analytical methods for analyzing transient processes in the discharge circuit of the installation; therefore, various methods of linearizing this resistance are usually used. The analysis in this work (as in most other works on this topic) was carried out under the assumption that the spark load has piecewise linear resistance. The value of this resistance is constant $\left(R_{\text {load }}=\right.$ const $)$ during each discharge with duration $t_{\text {discharge, }}$ but it can change stochastically during the pause between discharges (i.e. during the charge of the capacitor). Resistance $R_{\text {load }}$ is an energetically equivalent linear resistance, in which the same electrical energy is consumed as when the capacitor is discharged to a real nonlinear spark load. This linear resistance $R_{\text {load }}$ is determined by energy conditions



To increase the frequency of the charge-discharge cycles of the capacitor, and, consequently, the productivity of powder formation, most installations for VESD use the oscillatory mode of the capacitor discharge on a load with a some recharge (up to $30 \%$ of charge voltage of capacitor) [14] to the voltage of To increase the frequency of the charging-discharge cycles of the capacitor, and, consequently, the productivity of powder formation, most OEID units use the oscillatory mode of the capacitor discharge to the load with a slight overcharge (up to $30 \%$ of the capacitor charging voltage) [14] to the voltage of the opposite polarity. The simplest electrical equivalent circuit of the EDI's discharge circuit with a linear active resistance of the load is a series $R L C$ circuit switched by a semiconductor switch, in which $R$ is the total active resistance of the load, connecting wires and a semiconductor switch, $L$ is the inductance of the circuit, $C$ is the capacitance of the capacitor to be discharged. It is known that the maximum value of the oscillatory discharge current $I_{\max }$ with a quality factor of such a circuit $Q>2$ is directly proportional to the initial voltage on the capacitor during its discharge and the value of $\sqrt{C}$, and inversely proportional to the value of $\sqrt{L}$ [15]. Therefore, in most EDIs, the inductance $L$ is reduced to the lowest possible value. The amplitude of the current can be increased by increasing the charge voltage of the capacitor and its capacitance. However, an increase in the charging voltage of reservoir capacitors over $1000 \mathrm{~V}$ has serious technical limitations and significantly increases the risk of maintenance of EDIs. An increase in the capacitance $C$ leads to undesirable increase in both the duration of the discharge pulse $t_{D P}$ (since $t_{D P} \approx \pi \sqrt{L C}$ ) and the size of spark eroded powders obtained. Therefore, in this work, we studied the transients of the capacitor discharge to the load in the case of increase in the capacitance $C$ and the forced limitation of the pulse current duration $t_{D P}$ using a fully controlled semiconductor switch (IGBT transistor), which breaks the discharge circuit at the required time.

The circuit diagram of the discharge circuit of the installation for VESD using IGBT transistor as a fully controlled switch is shown in Fig. 1. To reduce the inductance of the discharge circuit of this installa-

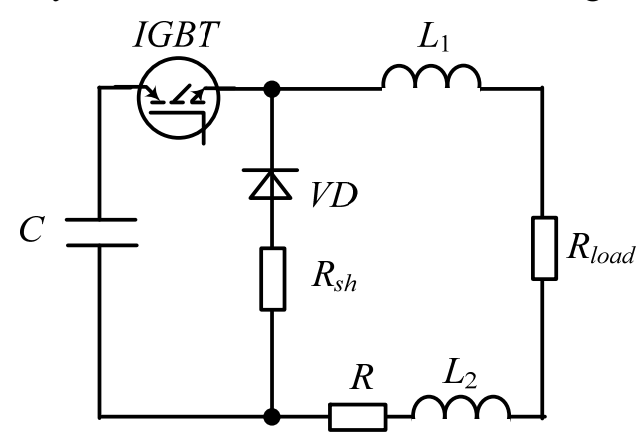

Fig. 1 tion, the connection to the load is structurally made with a coaxial power cable. The inductance of the cable has a distributed nature. In the circuit diagram, this distributed inductance is represented by two lumped chokes with inductances $L_{1}$ and $L_{2}$. Precharged reservoir capacitor $C$ is discharges through the $C-I G B T$ $L_{1}-R_{\text {load }}-L_{2}-R-C$ circuit. The $R_{s h}-V D$ shunt circuit is turned on after switching off the IGBT and bypasses the part of the circuit with inductors in order to dissipate the energy stored in these inductors. Circuit designations: $R$ - active resistance of the discharge circuit (including coaxial cable and IGBT), $R_{\text {load }}-$ linearized resistance of technological load, $C$ - reservoir capacitor capacity, $L_{1}$ and $L_{2}$ - coaxial cable inductances, IGBT - fully controlled semiconductor switch (IGBT transistor), $R_{s h}$ - shunt resistance, $V D$ - diode. 
Analysis of the average rate of rise of the discharge current with a fixed duration, which is less than the duration of reaching its maximum value. In most cases, the operating modes of the capacitor discharge to the load in such installations are oscillatory modes.

Analysis of the oscillatory discharge of a capacitor. In the general case, the current of the oscillatory discharge of a capacitor in an $R L C$ circuit can be calculated by the formula [15].

$$
i(t)=U_{0 C} e^{-\omega_{01} t / 2 Q} \sin \left(\omega_{0} B t\right) / L \omega_{0} B,
$$

where $U_{0 C}$ is the initial voltage of the capacitor during its discharge, $\omega_{0}=\sqrt{1 / L C}$ and $Q=\sqrt{L} /(\sqrt{C} \cdot R)$ is the respectively, the frequency of natural oscillations and the quality factor of the discharge circuit, $B=\sqrt{1-1 / 4 Q^{2}}$. It should be noted that for the circuit in Fig. 1 inductance $L=L_{1}+L_{2}$, and resistance $R=R_{\text {load }}+R$.

When the quality factor $Q>2$ (it is assumed that $B \approx 1$ and $e^{-\omega_{0} t / 2 Q} \approx 1$ ) formula (1) is simplified:

$$
i(t)=U_{0 C} \sin \left(\omega_{0} t\right) / L \omega_{0} \text {. }
$$

For most spark installations, the minimum value of the discharge circuit inductance is $L \approx 1 \mu \mathrm{H}$. By connecting the load with a coaxial cable (instead of wires), we were able to further reduce the inductance of the discharge circuit. The inductance of the discharge circuit of the experimental spark installation, on which we studied transient processes, was reduced to $0.7 \mu \mathrm{H}$. Therefore, the determination of the regularities of the change in the discharge currents while limiting their duration and increasing the capacity of the discharged capacitor was carried out under the assumption that $L=0.7 \mu \mathrm{H}=$ const.

The maximum value of the discharge current $I_{\max }$ can be written in accordance with (2) as follows:

$$
I_{\text {max }}=A / \omega_{0},
$$

where $A=U_{0 C} / L$ is the constant coefficient, and $\sin \left(\omega_{0} t_{\max }\right)=1\left(t_{\max }\right.$ is the time point corresponding to the maximum value of the discharge current). written using (2):

For any fixed time $t_{f i x}<t_{\max }$, during which the discharge current reaches the value $I_{f i x}<I_{\max }$, can be

$$
A \cdot \sin \left(\omega_{0} t_{f i x}\right) / \omega_{0}=A / N \text {, }
$$

where $N$ is the constant coefficient (which has the dimension of the angular frequency) for which the inequality $N>\omega_{0}$ is satisfied.

Let us differentiate function (2) with respect to the parameter $\omega_{0}$. Since the function $i\left(\omega_{0}\right)$ is continuous and differentiable in the entire domain of definition, we obtain

$$
\operatorname{di}\left(\omega_{0}\right) / d \omega_{0}=A\left[\omega_{0} t \cdot \cos \left(\omega_{0} t\right)-\sin \left(\omega_{0} t\right)\right] / \omega_{0}^{2} .
$$

According to the definition, the coefficient $A>0$ and $\omega_{0}{ }^{2}>0$, then the sign of the derivative $\operatorname{di}\left(\omega_{0}\right) / d \omega_{0}$ is determined by the factor in square brackets of expression (5), which we denote by the function $f\left(\omega_{0}\right)$ :

$$
f\left(\omega_{0}\right)=\left[\omega_{0} t \cdot \cos \left(\omega_{0} t\right)-\sin \left(\omega_{0} t\right)\right], \omega_{0} \in(0 ; N) .
$$

For $\omega_{0}=0$ (the lower boundary of the definitional domain), the function $f\left(\omega_{0}\right)=0$. To determine the sign of the function $f\left(\omega_{0}\right)$ on the rest of the definitional domain $0<\omega_{0}<N$ and for $\forall t>0$, the derivative of this function was studied:

$$
d f\left(\omega_{0}\right) / d \omega_{0}=-\omega_{0} t^{2} \cdot \sin \left(\omega_{0} t\right)
$$

For the first period of the oscillatory discharge of the capacitor, when $\sin \left(\omega_{0} t\right)>0$, we can say that $f^{\prime}\left(\omega_{0}\right)<0$ for $0<\omega_{0}<N$ and $\forall t>0$.

Thus, the function $f\left(\omega_{0}\right)<0<0$ over the whole definitional domain, and, consequently, also the derivative $\operatorname{di}\left(\omega_{0}\right) / d \omega_{0}<0$ for $\forall t>0, \omega_{0} \in(0, N)$. Therefore, the function $i\left(\omega_{0)}\right)$ for any current time $t_{k}$ decreases with increasing $\omega_{01}$, and, accordingly, it increases with increasing capacitance $C$, since the value of $\omega_{01}$ is inversely proportional to $\sqrt{C}$.

So, it can be concluded that, in the case of oscillatory discharge modes of a capacitor, an increase in its capacitance leads to an increase in the discharge current at any time moment $t_{f i x}<t_{\max }$.

Analysis of the aperiodic discharge of a capacitor. In the general case, the capacitor aperiodic discharge current is determined by the function [15] 


$$
i(t)=A e^{-\alpha t}\left(e^{\sqrt{\alpha^{2}-\omega_{0}^{2}} t}-e^{-\sqrt{\alpha^{2}-\omega_{0}^{2}} t}\right) / 2 \sqrt{\alpha^{2}-\omega_{0}^{2}},
$$

where $\alpha=\left(R_{\text {load }}+R\right) / 2\left(L_{1}+L_{2}\right)$.

Let us differentiate this function with respect to the parameter $\omega_{0}$. Since the function i $(\omega 01)$ is continuous and differentiable in the entire domain of definition, then it can be written

$$
\operatorname{di}\left(\omega_{0}\right) / d \omega_{0}=A \omega_{0} e^{-\alpha t}\left[\operatorname{sh}\left(t \sqrt{\alpha^{2}-\omega_{0}^{2}}\right)-t \sqrt{\alpha^{2}-\omega_{0}^{2}} \cdot \operatorname{ch}\left(t \sqrt{\alpha^{2}-\omega_{0}^{2}}\right)\right] /\left(\alpha^{2}-\omega_{0}^{2}\right) .
$$

Since the factors $A$ and $e^{-\alpha \cdot t}$ are positive and we consider an aperiodic process, in which $\alpha^{2}-\omega_{0}{ }^{2}>0$ (i.e. $\omega_{0} \in(0, \alpha)$ ), the sign of the derivative $d i\left(\omega_{0}\right) / d \omega_{0}$ is determined by the coefficient in square brackets of expression (9), which we denote as a function of $F\left(\omega_{0}\right)$ :

$$
F\left(\omega_{0}\right)=\left[\operatorname{sh}\left(t \sqrt{\alpha^{2}-\omega_{0}^{2}}\right)-t \sqrt{\alpha^{2}-\omega_{0}^{2}} \cdot \operatorname{ch}\left(t \sqrt{\alpha^{2}-\omega_{0}^{2}}\right)\right], \quad \omega_{0} \in(0, \alpha) .
$$

For $\omega_{01}=\alpha$ (the upper boundary of the domain of definition) the function $F\left(\omega_{0}=\alpha\right)=0$. To determine the sign of the function $F\left(\omega_{0}\right)$ for $0<\omega_{0}<\alpha$ and $\forall t>0 \square$, its derivative was studied:

$$
F^{\prime}\left(\omega_{0}\right)=\omega_{0} \cdot t^{2} \cdot \operatorname{sh}\left(t \sqrt{\alpha^{2}-\omega_{0}^{2}}\right) .
$$

From the fact that $t>0$ and $\sqrt{\alpha^{2}-\omega_{0}^{2}}>0$, it follows that $\operatorname{sh}\left(t \sqrt{\alpha^{2}-\omega_{0}^{2}}\right)>0$. Then knowing that $\omega_{0}>0$, we can say that $F^{\prime}\left(\omega_{0}\right)>0$ for $0<\omega_{0}<\alpha$ and $\forall t>0$.

Thus, the function $F\left(\omega_{0}\right)<0$ over the whole definitional domain, and, therefore, the derivative $\operatorname{di}\left(\omega_{0}\right) / d \omega_{0}<0$ for $\forall t>0, \omega_{0} \in(0, \alpha)$. Therefore, the function $i\left(\omega_{0}\right)$ for any current time $t_{k}$ decreases with increasing $\omega_{0}$, and, accordingly, increases with increasing capacitance $C$, due to the fact that the value of $\omega_{0}$ is inversely proportional to the value $\sqrt{C}$.

So we can conclude that in aperiodic capacitor discharge modes (as in oscillatory discharges), an increase in the capacitor's capacitance leads to an increase in the discharge current at any time $t_{f i x}<t_{\max }$.

Determination of the possibilities of regulating the rate of rise of the discharge current in the load when changing the capacity of the reservoir capacitor and the selected duration of this current. The transients of the capacitor discharge to the load were studied on the mathematical model of the discharge

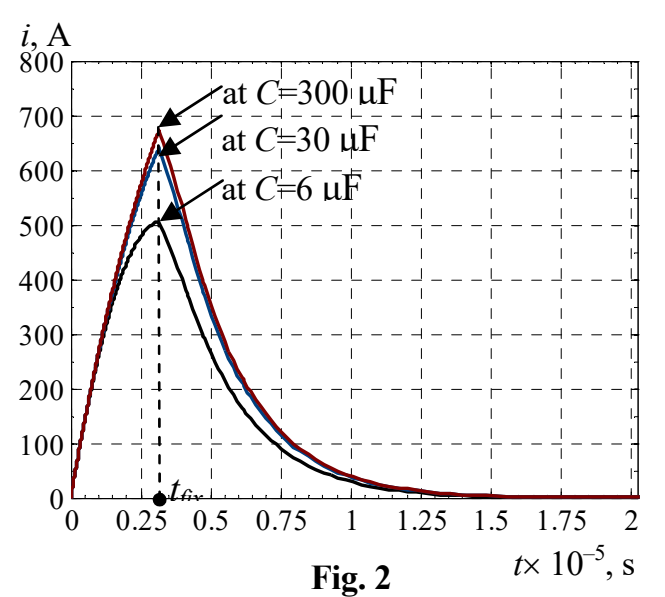
circuit of the installation for VESD (Fig. 1), implemented in the Mathlab Simulink software package. The circuit parameters in the simulation were selected corresponding to the parameters of the experimental installation: $R_{\text {load }}=0.2 \Omega, L_{1}=L_{2}=0.5 \mu \mathrm{H}$, $R=20 \mathrm{~m} \Omega, R_{\text {sh }}=0.2 \Omega$. The capacitance of the capacitor $C$ varied in a wide range from 6 to $300 \mu \mathrm{F}$ at the initial voltage of the capacitor $U_{0 C}=300 \mathrm{~V}$. At $C=6 \mu \mathrm{F}$ or $C=30 \mu \mathrm{F}$, the capacitor discharge has an oscillatory nature, and at $C=300 \mu \mathrm{F}$, it is aperiodic (in the absence of a forced break of the discharge circuit by the IGBT transistor).

At a certain point in time $t_{f i x}<t_{\max \text { at } C \min }$ (where $t_{\max \text { at } C \min }$ is the time during which the current corresponding to the smallest of the considered values of the capacitance $C$ reaches its maximum value), the fully controlled switch (IGBT) will begin to break the

discharge circuit.

Fig. 2 shows the curves that reflect the change in discharge current in the load for three values of capacitor capacity: $C=6 ; 30 ; 300 \mu \mathrm{F}$ and when this current is interrupted at $t_{f i x}=3.15 \mu$ s (whereas $t_{\max }$ at $\left.\operatorname{Cmin}=3.32 \mu \mathrm{s}\right)$.

Mathematical analysis of the functions that describe the discharge currents of the oscillatory and aperiodic discharge of the capacitor with increasing capacity, as well as analysis of the simulation results presented in Fig. 2, shows that with increasing capacitance $C$, the current $I_{f i x}$ increases regardless of the nature of the discharge. It should be noted that with a multiple increase in capacity $C$, the increase in $I_{f i x}$ becomes less and less significant. 
Thus, with an increase in the capacitance $C$ from 6 to $30 \mu \mathrm{F}$ (5 times), the $I_{f x}$ value increases by $27 \%$, and with a further increase in $C$ from 30 to $300 \mu \mathrm{F}$ (10 times), $I_{f x x}$ increases by only $6 \%$.

Analysis of expression (8) shows that if the capacitance $C$ exceeds some boundary value $C_{b}\left(C>C_{b}\right)$, at which $\alpha^{2}>>\omega_{0}^{2}$, then expression (8) can be transformed to the form

$$
i(t) \approx U_{0 C}\left(1-e^{-\left(R_{\text {load }}+R\right) t /\left(L_{1}+L_{2}\right)}\right) /\left(R_{\text {load }}+R\right) .
$$

As can be seen from this expression, the current $i(t)$ does not depend on the value of the capacitance $C$. That is, when the capacitance increases above the value of $C_{b}$, the discharge current curve asymptotically approaches the curve described by expression (12). Therefore, an excessive increase in the capacitance $C$ of the capacitor does not significantly change the $I_{f i x}$ value and the rate of current rise $I_{f i x} / t_{f i x}$.

Fig. 2 shows that the discharge duration in the load is approximately $15 \mu$ s for all considered values of $C$. Our studies have shown that if you use a thyristor (that is, a semi-controlled switch) instead of an IGBT in the discharge circuit, then the discharge duration prolongs significantly with increasing $C$. For example, at $C=300 \mu \mathrm{F}$, the discharge duration is $375 \mu \mathrm{s}$, that is, it increases 25 times, which inadmissibly reduces the frequency of discharge cycles.

The oscillogram of the current in the load, taken on a laboratory setup (with a discharge circuit as in Fig. 1), in which the above-described method of increasing the rate of current rise was implemented, is shown in Fig. 3, a. The oscillogram was obtained using a current sensor with a conversion factor 1:100 (V / A) and the HAMEG-HM-1507 oscilloscope. The division values on the oscillogram: for voltage (current) $-200 \mathrm{mV} /$ division ( $20 \mathrm{~A} /$ division), and for time $-2 \mu \mathrm{s} /$ division.

The parameters of the discharge circuit of this installation: $C=300 \mu \mathrm{F}, R_{\text {load }}=1 \Omega, L_{1}=L_{2}=0.7 \mu \mathrm{H}$, $R=20 \mathrm{~m} \Omega, R_{s h}=3 \mathrm{~m} \Omega$. The initial voltage on the capacitor was $U_{0 C}=130 \mathrm{~V}$. The IGBT module SKM300GB12T4 was used. Fig. 3, $b$ shows the result of simulation of the discharge current in the load of such an installation. Comparative analysis of the curves in Fig. 3, $a$ and $b$ shows sufficient accuracy of their coincidence (error does not exceed 7\%).
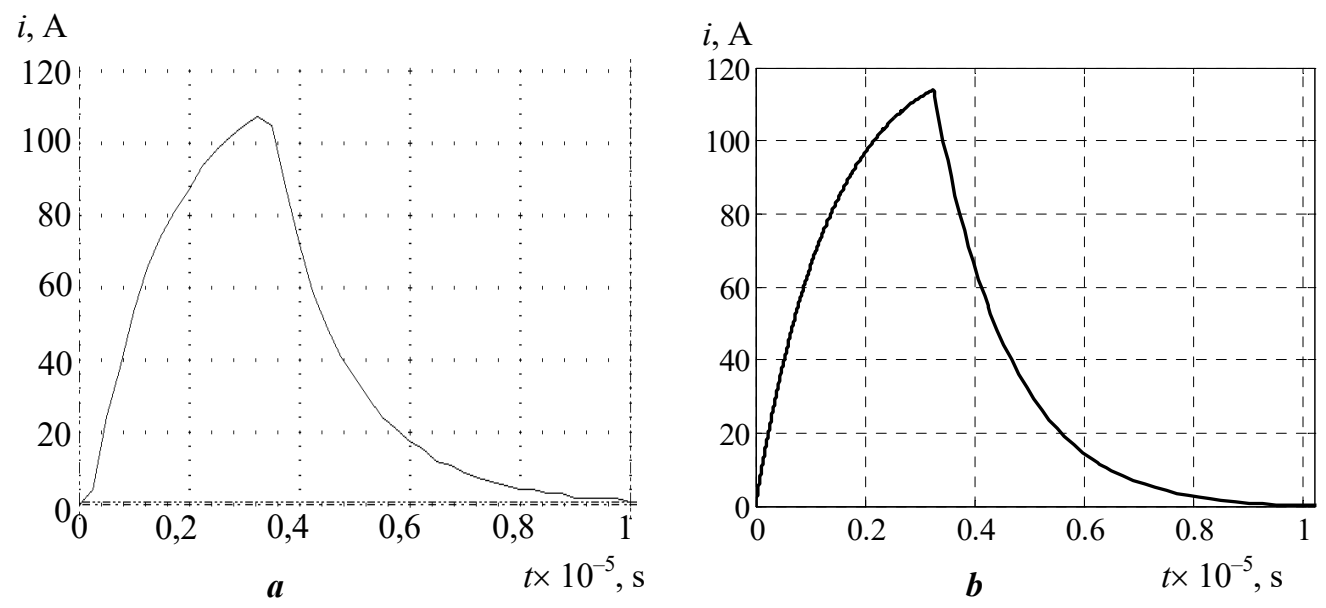

Fig. 3

Previously, the aperiodic discharge mode was unacceptable for installation for VESD of metal because of unacceptably long duration of the discharge pulse in the load, which resulted in the impossibility of realizing high frequencies of the charge-discharge cycles of the capacitor forming discharge pulses (and, consequently, low powder formation performance). When using the proposed method, the aperiodic discharge mode becomes desirable. This is due to the fact that the real resistance of the spark load is not constant during the discharge of the capacitor. It changes according to the law of the U-shaped function (when the current increases to the maximum value, the load resistance decreases to the minimum value, and then when the discharge current decreases, the resistance increases again) [11]. In installations for VESD of metals, a decrease in the load resistance (with an increase in the discharge current) is an additional factor influencing an even greater increase in this current, including its value $I_{f i x}\left(t_{f i x}\right)$. In addition, a characteristic increase in the value of the load resistance at the end of the discharge pulse will help to reduce the dynamic losses in the semiconductor switch, since at the same value of the discharge current, the voltage drop across the real load resistance will increase, and, therefore, more power will be dissipated in this resistance in comparison with power dissipated in equivalent linear resistance $R_{\text {load }}$. 
To implement the algorithm of the control system of such EDIs, it is necessary to take into account that due to a change in the resistance of the spark-erosion load from one discharge to another discharge, the current will increase to different values by the time $t_{f i x}$. Thus, the current value and the rate of its rise will vary within a certain range. In this case, with an increase in the capacitance of the capacitor, it is necessary to take into account the possibility that with a significant decrease in the load resistance, the current value may exceed the technologically permissible value. Therefore, in addition to $t_{f x}$, the maximum permissible value of the current $I_{\text {perm }}$ is also set, upon reaching which the discharge process must be forcibly interrupted.

When implementing such a way for generating discharge pulses with an increased rate of current rise, an increase in the capacitance of the ERU capacitor leads not only to an increase in the discharge current and the rate of its rise, but also to an increase in the average pulse power released in the load.

Conclusions. The regularities of the change of the output currents of semiconductor electric discharge installations with a storage capacitor depending on the capacitance of this capacitor and the conditions of limiting the duration of currents are investigated. It is analytically proved that for an arbitrary mode (oscillatory or aperiodic) of the capacitor discharge, an increase in its capacitance at constant other parameters of the discharge circuit leads to an increase in the output current at any fixed time $t_{f i x}$, less than the time $t_{\max }$, which corresponds to the maximum value of this current.

We propose to regulate the main output dynamic characteristics of electric discharge installations with storage capacitors (in particular, to increase the rate of rise and/or reduce the duration of their discharge-pulse currents in the load) by increasing the capacity of the discharge capacitor in comparison with the capacity sufficient to implement the required technological mode, and forced interruption of the current in the load when it reaches the required maximum value).

This approach is expedient for increasing the productivity of EDIs, focused on the production of dispersed spark powders of metals and alloys.

The work was performed at the expense of scientific work "Creation of scientific and technical bases of intellectualization of technological processes and means of measurement, control, monitoring and diagnostics in electric power and electro-technical systems (code: INTEHEN)" within the target program of scientific researches "Fundamental Research on Energy Transformation and Utilization Processes" under the Budget Program "Supporting the Development of Priority Areas of Research" (code of programmatic classification of expenditures 6541230).

1. Vovchenko A.I., Tertilov R.V. Synthesis of nonlinear parametric capacitive energy sources for a discharge pulse technologies. Zbirnyk naukovyh prats Natsionalnoho universytetu korablebuduvania. 2010. No 4. Pp. 118-124. (Rus)

2. Kravchenko V.I., Petkov A.A.. Parametrical synthesis of high-voltage pulse test devices with capacitive energy storage. Electrical Engineering \& Electromechanics. 2007. No 6. Pp. 70 - 75.

3. Shcherba A.A., Suprunovska N.I. Electric Energy Loss at Energy Exchange Between Capacitors as Function of Their Initial Voltages and Capacitances Ratio. Tekhnichna Elektrodynamika. 2016. No 3. Pp. 9-11. DOI: https://doi.org/10.15407/techned2016.03.009

4. Beletsky O.A., Suprunovska N.I., Shcherba A.A. Dependences of power characteristics of circuit at charge of supercapacitors on their initial and final voltages. Tekhnichna Elektrodynamika. 2016. No 1. Pp. 3-10. (Ukr) DOI: https://doi.org/10.15407/techned2016.01.003

5. Liu Y., Li X., Li Y., Zhao Zh., Bai F. The lattice distortion of nickel particles generated by spark discharge in hydrocarbon dielectric mediums. Applied Physics A. 2016. Vol. 122. Pp. 174-1 - 174-9. DOI: https://doi.org/10.1007/s00339-016-9698-2.

6. Casanueva R., Azcondo F.J, Branas C., Bracho S. Analysis, design and experimental results of a high frequency power supply for spark erosion. IEEE Transactions on Power Electronics. 2005. Vol. 20. Pp. 361-369. DOI: https://doi.org/10.1109/TPEL.2004.842992

7. Nguyen, P.K., Sungho J., Berkowitz A.E. MnBi particles with high energy density made by spark erosion. $J$. Appl. Phys. 2014. Vol. 115. Iss. 17. Pp. 17A756-1. DOI: https://doi.org/10.1063/1.4868330.

8. Kornev Ia., Saprykin F., Lobanova G., Ushakov V., Preis S. Spark erosion in a metal spheres bed: Experimental study of the discharge stability and energy efficiency. Journal of Electrostatics. 2018. Vol. 96. Pp. 111-118. DOI: https://doi.org/10.1016/j.elstat.2018.10.008.

9. Nguyen P.K., Lee K.H., Kim S.I., Ahn K.A., Chen L.H., Lee S.M., Chen R.K., Jin S., Berkowitz A.E. Spark Erosion: a High Production Rate Method for Producing Bi0.5Sb1.5Te3 Nanoparticles With Enhanced Thermoelectric Performance. Nanotechnology. 2012. Vol. 23. Pp. 415604-1 - 415604-7.

10. Shydlovska N.A., Zakharchenko S.M., Cherkassky O.P. The analysis of electromagnetic processes in output circuit of the generator of discharge pulses with non-linear model of plasma-erosive load at change their parameters in wide ranges. Tekhnichna Elektrodynamika. 2016. No 1. Pp. 87-95. (Rus) DOI: https://doi.org/10.15407/techned2016.01.087.

11. Suprunovska N.I., Ivashchenko D.S. Multilevel model of interdependent transients in circuits of electrodischarge installations with stochastic load. Tekhnichna Elektrodynamika. 2013. No 5. Pp. 5-13. (Rus) 
12. Shydlovska N.A., Zakharchenko S.M., Cherkassky O.P. Model of an output circuit of the discharge pulses generator with a plasma-erosive load adequate in wide range of changes of their parameters. Tekhnichna Elektrodynamika. 2015. No 6. Pp. 69-77. (Rus)

13. Zakharchenko S.N., Kondratenko I.P., Perekos A.E., Zalutsky, V.P., Kozyrsky V.V., Lopatko K.G. Influence of discharge pulses duration in a layer of iron granules on the size and structurally-phase conditions of its electroerosion particles. Eastern-European Journal of Enterprise Technologies. 2012. Vol. 6. No 5 (60). Pp. 66-72. (Rus)

14. Ivashchenko D.S., Suprunovska N.I. Transients in circuits with stochastic load, which characterized by continuous random variable. Tekhnichna Elektrodynamika. 2016. No 4. Pp. 17-19. (Rus) DOI: https://doi.org/10.15407/techned2016.04.017

15. Demirchyan K.S., Nejman L.R., Korovkin N.V., Chechurin V.L. Electrical engineering theory. Vol. 2. SaintPetersburg: Piter, 2003. 576 p. (Rus)

\section{РЕГУЛЮВАННЯ ВИХІДНИХ ДИНАМІЧНИХ ХАРАКТЕРИСТИК ЕЛЕКТРОРОЗРЯДНИХ УСТАНОВОК 3 НАКОПИЧУВАЛЬНИМИ КОНДЕНСАТОРАМИ}

А.А. Щерба ${ }^{1}$, чл.-кор. НАН України, Н.І. Супруновська ${ }^{1}$, докт. техн. наук, М.А. Щерба ${ }^{2}$, докт. техн. наук, С.С. Розіскулов ${ }^{1}$

${ }^{1}$ Інститут електродинаміки НАН України, пр. Перемоги, 56, Київ, 03057, Україна, e-mail: iednat1@gmail.com

${ }^{2}$ НТУ України "КПІ ім. Ігоря Сікорського", пр. Перемоги, 37, Київ, 03056, Україна, e-mail: m.shcherba@gmail.com

Виявлено залежності вихідних динамічних характеристик напівпровідникових електророзрядних установок (ЕРУ) з накопичувальними конденсаторами від особливостей змінення величини їхньої ємності. Зокрема обтрунтовано, щзо за фіксованій тривалості розряду, меншій від тривалості досягнення максимального розрядного струму, збільшення ємності таких накопичувачів викликає збільшення величини кінцевого розрядного струму як у разі формування аперіодичних, так і коливальних розрядів у лінійному опорі технологічного навантаження. Ємність розрядних конденсаторів у таких досліджуваннях змінювалася в широких межах. Досліджено змінення величини розрядного струму в навантаженні за його примусового переривання в певний момент часу. Базуючись на отриманих закономірностях, авторами запропоновано використовувати ємність конденсатора ЕРУ більшу, ніж потрібно задля реалізації у навантаженні максимального значення розрядного струму. Використовуючи в розрядному контурі ЕРУ конденсатор більшої ємності та повністю керований напівпровідниковий ключ, можна отримати необхідне максимальне значення струму за меншій тривалості розрядного процесу. Таким чином, зміненням величини ємності розрядного конденсатора ЕРУ можна регулювати основні динамічні параметри імпульсних струмів у навантаженні - швидкість їхнього наростання та/або їхню тривалість. Такий підхід є доиільним задля підвищення продуктивності ЕРУ, орієнтованих на виробництво дисперсних іскроерозійних порошків металів і сплавів. Бібл. 15, рис. 3.

Ключові слюва: розряд конденсатора, швидкість наростання струму, перехідний процес, ємність конденсатора, тривалість розряду. 